\title{
Analysis of Bone Variations of the Occipital Bone in Man
}

\author{
Análisis de las Variaciones del Hueso Occipital en el Hombre
}

*João Roberto da Mata; "Fabiana Ribeiro da Mata \& ${ }^{* *}$ Tales Alexandre Aversi-Ferreira

\begin{abstract}
DA MATA, J. R.; DA MATA, F. R. \& AVERSI-FERREIRA, T. A. Analysis of bone variations of the occipital bone in man. Int. J. Morphol., 28(1):243-248, 2010.

SUMMARY: Inadequate ossification of the interparietal region induces the appearance of interparietal and wormian bones, also associated with genetic factors. The formation of the interparietal bone depends on the separation of the intermediate segment from the lateral plate by the transverse occipital suture, which means that this bone is formed by the medial and lateral plates. Wormian interparietal bones or epactal bones are located within the interparietal region, being single or multiple, and are located in the upper central region of the interparietal region, the sutural bones, however, are formed from additional ossification centers that can occur in near sutures. The aim of this work was to macroscopically evaluated the presence of changes in the structure of the adult human occipital bone in cadavers found in the human anatomy laboratory of the Goiás Federal University in order to determine the frequency of supernumerary bones associated with occipital and parietal bones and relate it to literature, as well as to provide images and data for ethnic studies in the Brazilian population and data that could help medical practices such as fetal position and radiographs. Our data have indicated that the frequency of the interparietal bone of $1.92 \%$ is among those seen in countries such as Japan, Bulgaria, Nigeria, India and Turkey, but lower than values found in pre-Hispanics Chileans; however, for the sutural bones, the frequency of this study was higher than other data obtained from Spanish and other Brazilians.
\end{abstract}

KEY WORDS: Skull; Human; Interparietal bone; Sutural bone.

\section{INTRODUCTION}

The skull is most studied and documented part of the vertebrates skeleton, and also more important and complex (Testut \& Latarjet, 1958), maybe due to its relationship with the neural system and can be described, broadly, as a wrapper for tissues more or less rigid that, in animals from the craniata clade, involves the encephalon, organs of smell, vision and inner ear and serves to support the external organs of the respiratory and digestive apparatus, and defines the direction of animal's movement.

The bone and cartilaginous structures form the skull, and in terms of homology and phylogeny, bones and / or cartilage with the same name in fish are the counterparts in mammals and maintain more or less constant relationships with the neural system.

In the evolutionary scale, it is a well-noted and accepted fact that the skull of beings derived from the ancestors, in the case of human beings, have less bones than the others. It could be assumed from this data that bone fusions occurred, and this is really what occurred; however, other possibilities are possible such as the disappearance of bone parts of and / or primordial cartilages, or in some rare cases, a new bone has developed and shows no homology with the other if the latter is of dermal origin and the other is situated near of endochondral origin.

In more simple vertebrates, there are more bones and they are the basis of observation and study, since their general structure indicate the formation, by homology, of the skulls of derivative vertebrates and, for humans, the importance of knowing these data is related to the position of the fetus in the mother's womb (Testut \& Latarjet), with possibilities of measurement the position of the skull in radiographs (Yücel et al., 1998).

Differences in the skull ossification processes can generate, in adult humans, supernumerary bones or wormian

\footnotetext{
* Department of Morphology, Institute of Biological Sciences, Federal University of Goias, Brazil.

*** Neurosciences and Behaviour Primates Laboratory, Department of Nursing, Campus of Catalão, Federal University of Goiás, Brazil.
} 
bones, so considered in the description made by Olaus Worm in the seventeenth century (1611), but they are known from remote antiquity, since they were cited in the pharmacopoeias of Greeks physicians who employed them for the healing of neural diseases such as epilepsy, which are very variable in size, shape and thickness (Testut \& Latarjet; Matsumura et al., 1993, De Araujo et al., 2002).

According to Testut \& Latarjet, there are six fontanels in the fetus' skull, and the posterior fontanel (small fontanel or lambdoidea) corresponds to the points of convergence of the parietal bones with the occipital bone, has triangular shape, and is usually closed at birth.

Inadequate ossification in the interparietal region induces the appearance of interparietal and wormian bones (Testut \& Latarjet; Matsumura et al., 1994; Kodama, 1973, Pal et al., 1984, Pal et al., 1986, Pal et al., 1987; Yücel et al.), other authors believe that these bones have genetic origin (El-Najjar \& Dawson, 1977; García-Hernández \& Murphy-Echeverría, 2008).

According to Yücel et al., the formation of the interparietal bone depends on the separation of the intermediate segment from the lateral plate through transverse occipital suture, which means that this bone is formed by the medial and lateral plates.

Testut \& Latarjet believe that the epactal bones are false wormian bones, since they are not generated by the fusion of the adjacent bones to the fontanels, adding that the wormian bones may be sutural or fontanel bones and that the bones above may have confusing origin, since they are commonly confused with the epactal and interparietal bones, and what the authors regard as interparietal bone would not be more than part of the interparietal bone, which may have three parts, two lateral and one intermediate, while the epactal bone is a wormian bone by this concept, which does not occur with the interparietal bone.

The non-wormian interparietal bone originates from the lack of complete ossification of the occipital shell, the ossification process occurs laterally to the posterior midline and the meeting of these two centers firstly occurs at the height of this line, if synostosis of the lateral portions does not occur, the interparietal bone in adults is formed, or also called supraoccipital bone, which cannot be considered a wormian bone, being also visible as a bone structure formed between the occipital and parietal bones (Testut \& Latarjet).

Wormian interparietal bones or apactal bones are located within the interparietal region, being single or multiple, and are located in the upper central region of the interparietal region (Testut \& Latarjet), the sutural bone, however, are formed from additional ossification centers that may occur in sutures or near them (Wafae et al., 2007).

The non-wormian epactal or interparietal bone was firstly described by Saint-Hilaire (1823), and called the Inca bone by Tschudi (1844). Later, Shapiro \& Robinson (1976), verified the frequency of $5-23 \%$ of these bones in Inca skulls and García-Hernández \& Murphy-Echeverría reported the presence of these bones in $27.1 \%$ of preHispanic Chileans, higher frequencies than most of those found in other studies, which according to Shrivastava (1977) was 0.8\%, Singh et al. (1979) of 1.6\%, Pal et al. (1984) of $2.6 \%$, Cireli et al. (1985) of 4.0\%, Saxena et al. (1986) of 2.5\%, Magden \& Muftuoglu (1990) of 1.6\%, Gopinath (1992) of 0.8\%, Aycan (1993) of 6.6\%, Katkici et al. (1995) of $0.99 \%$, Yücel et al. of $2.8 \%$ and Zambare (2001) of $0.99 \%$.

The texts used for study in graduate programs mention the presence of interparietal and sutural bones, but without illustration (Warwick \& Williams, 1979), others programs do not mention or illustrate them (Gardner et al., 1960, Gardner \& Osburn, 1980; Lockhart et al., 1983; O'Rhailly, 1985; Figun \& Garino, 1989, Fehrenbach et al., 1998, Costa et al., 2000; Dangelo \& Fattini, 2000, Moore \& Dalley, 2001; Madeira, 2004; Schunke et al., 2007) and others only illustrate them (Sobbota, 2000, WolfHeidegger, 2006); however, Testut \& Latarjet conducted a thorough study on these bones, citing them and illustrating them in details.

Papers on sutural (García-Hernandez et al. 2007; Wafae et al.; Nayack, 2008) and interparietal bones (Yücel et al.; Zambare; García-Hernandez \& Murphy-Echeverría) have been published; however, they do not consider the name of epactal bone for the wormian interparietal bone, and according to Testut \& Latarjet, and in this article, this is due to the detailed description on the latter, when using for assigning the ecpactal bones, sutural and interparietal bones.

The aim of this work was to macroscopically evaluated the presence of changes in the structure of the adult human occipital bone in cadavers found in the human anatomy laboratory of the Goiás Federal University in order to determine the frequency of supernumerary bones associated with occipital and parietal bones and relate it to literature, as well as to provide images and data for ethnic studies in the Brazilian population and data that could help medical practices such as fetal position and radiographs. 


\section{MATERIAL AND METHOD}

One hundred and four macerated adult human skulls were studied, with synostosis of the sphenoccipital suture from both genders and unknown ethnicity, belonging to the ossuary of the Goiás Federal University (UFG). The skulls were macroscopically observed with naked eye and with magnifying glass and photographed for further analysis. The statistical method used was the percentage relative frequency.

\section{RESULTS}

Bone variations occurred in $45.2 \%$ of cases. There was a higher incidence of sutural bone in the presence of wormian interparietal (epactal) and non-wormian bones (Table I).

The epactal bone had rare occurrence with only $1.92 \%$ of cases, being an individual case and the other multiple. The non-wormian interparietal bone occurred along the lambdoidal suture at the left and right in locations more or less symmetrical and with larger size for the right interparietal bone (Fig. 1). The same percentage (1.92\%) was observed for the wormian interaparietal bone (Table I); however, appearing only as individual occurrences (Figs. 1 and 2). The non-wormian interparietal bones were observed in the inferior-posterior region to the lambdoidal suture, in the upper angle of the occipital bone and above the external occipital protuberance.

The sutural bones (Fig. 3) occurred in (89.7\%) in the lambdoidal suture region (Fig. 3) and $10.26 \%$ in the lambda region. This study observed $21.15 \%$ of occurrences of multiple sutural bone, and from these, $7.7 \%$ are double and $1.92 \%$ are triple (Table I). These bones are presented preferably in the elongated shape and sometimes rounded.

\section{DISCUSSION}

Mammals appear to be descendants of synapsid reptile primitives, which is one of the order of therapsids, which had a lateral hole in the temporal region on each side of the head, the main changes occurred in the mammalian skull with many fusions and loss of skeletal elements, but in general, mammals have a pair of occipital condyles, two openings (the acoustic canal) and a change of considerable proportions of skeletal elements; however, between groups of mammals, changes of considerable bone proportion also occur (Storer et al., 2000).

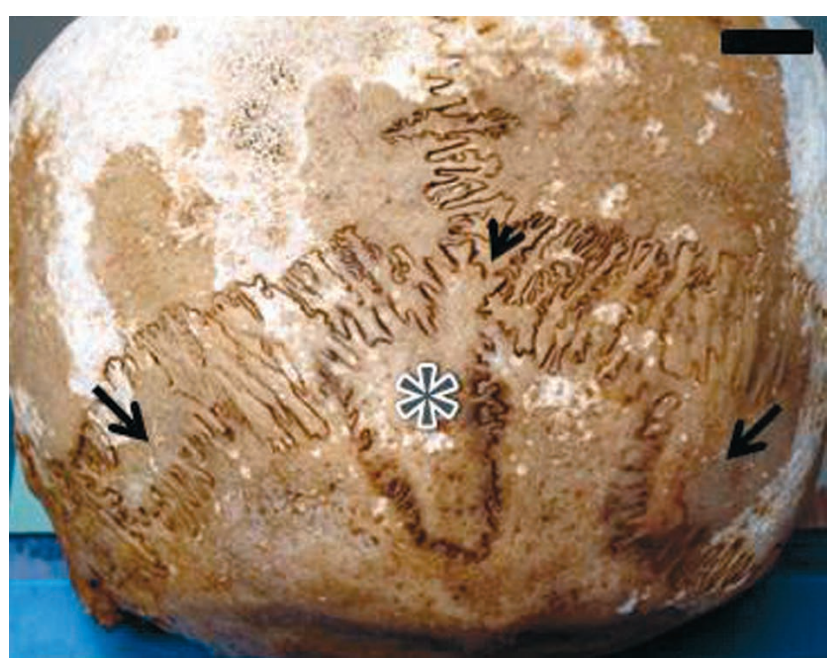

Fig. 1. Adult human skull of unknown gender and ethnicity. The presence of multiple interparietal bones (arrow), non-wormian interparietal or epactal bones (*) and sutural bone (head of arrow) is observed $(\mathrm{bar}=1.25 \mathrm{~cm})$.

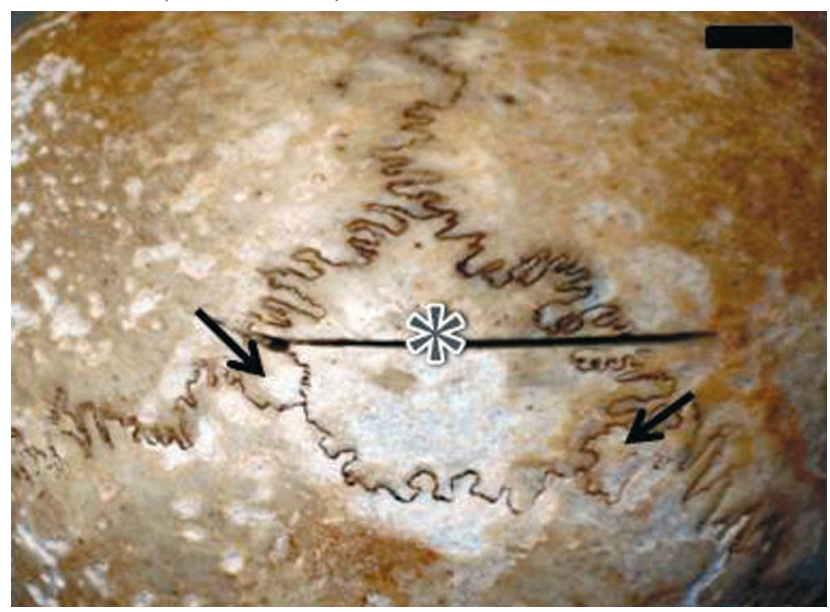

Fig. 2. Adult human skull of unknown gender and ethnicity. The presence of epactal bone (*), and sutural bones (arrows) in the lambdoidal suture is observed $(\mathrm{bar}=1 \mathrm{~cm})$.

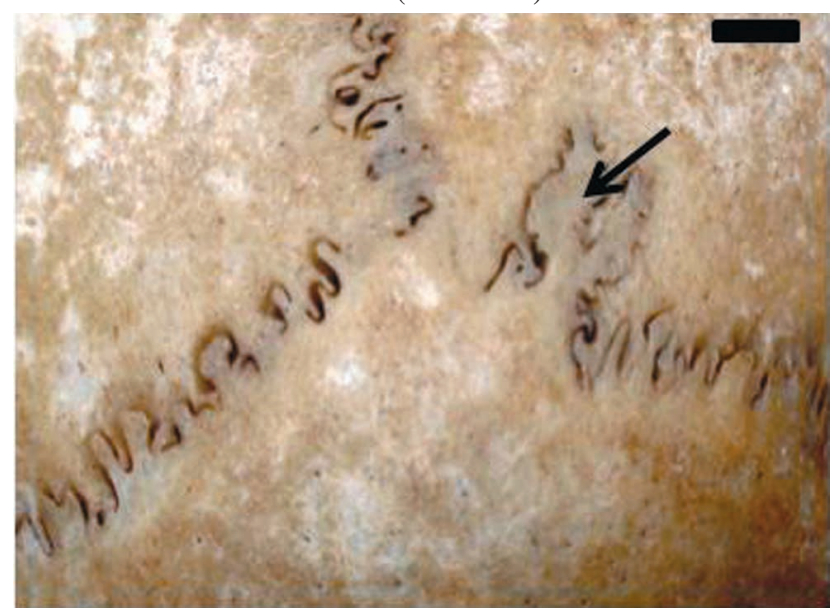

Fig. 3. Adult human skull of unknown gender and ethnicity. The sutural bone (black arrow) is observed (bar $=0.83 \mathrm{~cm}$ ). 
Table I. Occurrences of variations in the occipital bone of macerated adult human skulls from both genders and unknown ethnicity. One hundred and four skulls were analyzed.

\begin{tabular}{|c|c|c|c|c|}
\hline Types of occurrences & & Type of Bone & & Total \\
\hline & Epactal or wormian interparietal bone & Non-w ormian Interparietal bone & Sutural (womian) & \\
\hline Individual & $1(0.96 \%)$ & $2(1.92 \%)$ & $21(20.19 \%)$ & $24(23.1 \%)$ \\
\hline Multiple & $1(0.96 \%)$ & 0 & $22(21.15 \%)$ & $23(22.1 \%)$ \\
\hline Total & $2(1.92 \%)$ & $2(1.92 \%)$ & $43(41.35 \%)$ & $47(45.2 \%)$ \\
\hline
\end{tabular}

The post-orbital bone disappeared and with it, all other primitive orbital elements. The post-parietal bone was fused with the occipital bone (only in humans); however, atavistic factors (Yücel et al.) seem to direct the production of supernumerary bone in humans such as sutural, epactal and interparietal bones. In primates, the dermal bones of the superior-anterior portion of the skull were too huge to host a brain of immense proportions in relation to the other animals.

It is possible to verify that the parietal bone is derived from bone fusions phylogenetically older and that variations in the bone formation processes should occur in the ossification process (Testut \& Latajet), since, according to data of this article, the sutural bones were the most frequent, with distribution throughout the lambdoidal suture and smaller than those presented by epactal and interparietal bones, which is similar to data found in literature (Srivastava; Saxena et al.; De Araujo et al.; Wafae et al.;García- Hernández et al.).

Our data indicate that the frequency of the interparietal bone of $1.92 \%$ is among those seen in countries such as Japan, Bulgaria, Nigeria and India (De Araújo et al.), Turkey (Yücel et al.), but lower than values found in pre-Hispanic Chileans (García-Hernández \& Murphy-Echeverría); however, for the sutural bones (41.5\%), the frequency of this study was higher than the $16 \%$ shown by De Araujo et al. and Krogman \& Iscan (1986), also higher than the $36 \%$ found in Brazilians by Wafae et al. It is important to emphasize that Wafae et al. and García-Hernández \& Murphy-Echeverría do not consider that the sutural bones are associated with ethnic groups, and these data and those from this article place the genetic hypothesis in doubt; however, El-Najjar \& Dawson, mentioned that the sutural bones may have genetic or metabolic origin.

The interparietal and epactal bones, due to their low prevalence in this study, may be linked to genetic and ethnic characteristics, since García-Hernández et al. cite the presence of these bones in $27.1 \%$ of pre-Hispanic Chileans, which is a difference difficult to be explained only by stochastic factors; however, for the skulls of Turks, Yücel et al. report that the presence of these bones is associated with abnormalities of fusions of ossification centers of the interparietal bone.
However, there are reports of the appearance of sutural bones in diseases with bone involvement (Pryles \& Khan, 1979; Castaño-Duque et al., 1998; Das et al., 2005).

The importance of this subject during the graduation program, due to the presence of these variations in the occipital bone, has been low, which was evidenced by the poor illustration and description found in specialized books. The absence of reports that actually find the meaning of the presence of these variations in the living individual may explain this fact.

Thus, the values observed in this study are consistent with the percentages already established, except for interparietal bones of pre-Hispanic Chileans; however, other approaches as for race, color and gender could not be assessed due to the lack of data that could allow these tests for this work.

We believe that raising the data of Testut \& Latarjet for a modern discussion associated with more recent authors and providing images for study, especially to generate evidences of localization in surgeries and fetal position indicate that further studies should be performed in embryologic and phylogenetic terms to help determine the origin of these supernumerary bones, since some bone aspects of the head such as the difference in the synostosis time may show neural problems (Pryles \& Khan; Castaño-Duque et al.; Das et al.; Paik \& Byeon, 2010).

DA MATA, J. R.; DA MATA, F. R. \& AVERSI-FERREIRA, T. A. Análisis de las variaciones del hueso occipital en el hombre. Int. J. Morphol., 28(1):243-248, 2010.

RESUMEN: La osificación inadecuada de la región interparietal induce a la aparición de los huesos interparietal y wormiano, asociado también con factores genéticos. La formación del hueso interparietal depende de la separación del segmento intermedio desde la placa lateral por la sutura occipital transversal, lo que significa que este hueso se forma por las placas medial y lateral. Los huesos interparietales wormianos o hueso epactal se encuentram dentro de la región interparietal, siendo únicos o múltiples, y se localizan en la región central superior de la zona interparietal. Los huesos suturales, sin embargo, se forman de centros de osificación 
adicionales que pueden aparece cerca de estas suturas. El objetivo de este trabajo, fue evaluar macroscópicamente la presencia de variaciones en la estructura del hueso occipital en cadáveres humanos, adultos encontrados en el Laboratorio de Anatomía Humana de la Universidad Federal de Goiás, con la finalidad de determinar la frecuencia de los huesos supernumerarios asociados con los huesos parietal y occipital. Además, comparamos estos datos con los descritos enla literatura y, aportamos imágenes y datos para estudios étnicos en la población Brasileña. Estos datos pueden ayudar en las prácticas médicas como la posición fetal y radiografías. Nuestros datos indicaron que la frecuencia del hueso interparietal fue de 1,92\% y se encuentra en países como Japón, Bulgaria, Nigeria, India y Turquía, pero inferior a los valores encontrados en chilenos prehispánicos. Sin embargo, para los huesos suturales, la frecuencia de este estudio fue superior a otros datos obtenidos de españoles y otros estudios realizados en individuos brasileños.

PALABRAS ClAVE: Cráneo; Humano; Hueso interparietal; Hueso sutural.

\section{REFERENCES}

Aycan, K. Development of Interparietal bones and their variations. Erciyes Universities Saglik Billimleri Dergisis, 2:70-6, 1993.

Castaño-Duque, C. H.; Jori-Solé, F. J.; Quintero-Rivera, J. C.; Pons-Irazazabal, L. C. \& López-Moreno, J. L . Disostosis cleidocraneal. Presentación de un caso. Rev. Neurol., 27(159):838-41, 1998.

Cireli, E.; Ustun, E. E. \& Tetik, S. Os occipitale varyasyonlarive radyolojik Ozellikleri. Ege Universities Tip Faultesi Dergisi, 24:3-35, 1985.

Costa, C.; Costa, A. C. B. \& Savedra, C. M. Sistema ósseo. Fundamentos de anatomia para o estudante de odontologia. São Paulo, Atheneu, 2000.

Dangelo, J. G. \& Fattini, C. A. Anatomia Humana Sistêmica e Segmentar. $2^{\text {a }}$ Ed. São Paulo, Atheneu, 2000.

Das, S.; Suri, R. \& Kapur, V. Anatomical observations on os inca and associated cranial deformities. Folia Morphol., 64:118-21, 2005.

De Araujo, K. C. G. M.; Bittencourt, A. M.; Prado Reis, F. \& Tashiro, T. Ocurrence of the interparietal bone in human skulls. IV Congreso de Anatomía Del Cono Sur, Maceio, Brasil, 2002.

El-Najjar, M.Y. \& Dawson, G. L. The effect of artificial cranial deformation on the incidence of Wormian bones in the lambdoidal suture. Am. J. Phys. Anthropol., 46(1):155-
60, 1977.

Fehrenbach, M. J. \& Herring, S. W. Anatomia Ilustrada da Cabeça e do Pescoço. São Paulo, Manole Ltda., 1998.

García-Hernández, F.; Blanco, J. L. D. \& Murphy-Echeverría, G. Incidencia de Huesos Suturales en Cráneos de Changos del Norte de Chile, Región de Antofagasta. Int. J. Morphol., 25(4):801-4, 2007.

García-Hernández, F. \& Murphy-Echeverría, G. Frecuencia del Hueso Interparietal o Incaico en Cráneos Atacameños (Lican antai) Prehispánicos del Norte de Chile. Int. J. Morphol., 26(3):629-34 2008.

Figún, M. E. \& Garino, R. R. Anatomia Odontológica Funcional e Aplicada. 2a Ed. São Paulo, Panamericana, 1989.

Gardner, E.; Gray, D. J. \& O’Rahilly, R. Anatomy. Philadelphia, W. B. Saunders Company, 1960.

Gardner, W. D. \& Osburn, W. A. Anatomia do corpo humano. $2^{a}$ Ed. São Paulo, Atheneu, 1980.

Gopinathan, K. A rare anomaly of 5 ossicles in the preinterparietal part of the squamous occipital bone in north Indians. J. Anat., 180:201-2, 1992.

Katkici, U.; Gumusburun, E.; Erdil, H.; Sevim, A. \& Gulec, E. A study of incidence of the interparietal bone. J. Anat. Soc. India, 44(1):1-17, 1995.

Kodama, G. Developmental studies on the Squama occipitalis in the Human skull: with special reference to the development of the os Incae. Hokkaido Journal of Medical Science, 48:351-63, 1973.

Krogman, W. M. \& Iscan, M. Y. The Human Skeleton in Forensic Medicine. $2^{\text {nd }}$ Ed. Springfield, Charles C Thomas, 1986.

Lockhart, R. D.; Hamilton, G. F. \& Fyfe, F.W. Anatomia do corpo humano. 2a Ed. Rio de Janeiro, Guanabara Koogan, 1983.

Madeira, M. C. Anatomia da face: bases anatomo-funcionais para a prática odontológica. 5a Ed. São Paulo, Servier, 2004.

Magden, O. \& Muftuoglu, A. Insan democraniumunda sutural ve epectal kemiklerin varyasyonlari. Istanbul Universities Cerrahpasa Tip Fakultesi Dergisi, 21:319-23, 1990.

Matsumura, G.; England, M. A.; Uchiumi, T. \& Kodama, G. The fusion of ossification centres in the cartilaginous and membranous parts of the occipital squama in human fetuses. 
J. Anat., 185(2):295-300, 1994.

Matsumura, G.; Uchiumi, T.; Kida. R.; Ichirawa, R. \& Kodama, G. Developmental studies on the interparietal part of the human occipital squama. J. Anat., 182(2):197204, 1993.

Moore, L. K. \& Dalley, A. F. Anatomia orientada para a clínica. $2^{\text {a }}$ Ed. Rio de Janeiro, Guanabara Koogan, 2001.

Nayak, S. B. Multiple Wormian bones at the lambdoid suture in an Indian skull. Neuroanatomy, 7:52-3, 2008.

O’Rahilly, R. Anatomia humana básica. Rio de Janeiro, Interamericana, 1985.

Paik, H. \& Byeon, J. H. Anterior two-thirds calvarial remodelling: operative technique for the correction of metopic synostosis in toddlers. J. Plast. Reconstr. Aesthet. Surg., 63(1):36-41, 2010.

Pal, G. P.; Tamankar, B. P.; Routal, R. V. \& Bhagwat, S. S. The ossification of the membranous part of the squamous occipital bone in man. J. Anat., 138:259-66, 1984.

Pal, G. P.; Bhagwat, S. S. \& Routal, R. V. A Study of Sutural Bones in Gujarati (Indian) Crania. Anthropol. Anz., 44(1):67-76, 1986.

Pal, G. P. Variations of the interparietal bone in man. J. Anat., 152:205-8, 1987.

Pryles, C. V. \& Khan, A. J. Wormian bones. A marker of CNS abnormality? Am. J. Dis. Child., 133(4):380-2, 1979.

Saint-Hilaire, G.E. Considérations et Rapports Novaux Ostéologie Comparée Concernant les Animaux. Mem. Museum Histoire Naturelle Paris, 10:165, 1823.

Saxena, S. K.; Chowdhary, D.S. \& Jain, S.P. Interparietal bones in Nigerian skulls. J. Anat., 144:235-7, 1986.

Schunke, M.; Schulte, E.; Schumacher, U.; Voll, M. \& Wesker, K. Prometheus Atlas de Anatomia Cabeça $e$ Neuroanatomia. $1^{\text {a }}$ Ed. Rio de Janeiro, Guanabara Koogan, 2007.

Shapiro, R. \& Robinson, F. The Os Incae. Am. J. Roentgenol., 127:469-71, 1976.

Singh, P. J.; Gupta, C. D. \& Arora, A. K. Incidence of inteparietal bone in adultskulls of Agra Region. Anat. Anz., 145:528-31, 1979.

Sobotta, J. Atlas de Anatomia Humana. 21 Ed. Rio de Janeiro,
Guanabara Koogan, 2000. V. 1.

Srivastava, H. C. Developmental of ossification centres in the squamous portion of the occipital bone in man. J. Anat., 124:643-9, 1977.

Storer, T. I.; Usinger, R. L.; Stebbins, R. C. \& Nybackken, J. W. Zoologia General. 6a Ed. São Paulo, Companhia Editora Nacional, 2000.

Testut, L. \& Latarjet, A. Tratado de anatomía humana. $9^{\mathrm{a}}$ Ed. Barcelona, Salvat, 1958.

Tschudi, J. J. Uber Die Ureinwohner Von Peru. Arch. Anat. Physiol. Wiss Med., 98-109, 1844.

Wafae, N.; Ruiz, C. R.; Pereira, L. A.; Nunes, M. R.; Toito, E. \& Gomes, J. A. J. Quantitative analisys of the sutural bones in adult human skulls. Arq. Med. ABC, 32(2):67-9, 2007.

Warwick, R. \& Willians, P. L. Gray Anatomia. $35^{\text {a }}$ Ed. Rio de Janeiro, Guanabara Koogan, 1979. Tomo 1.

Wolf-Heidegger. Atlas de Anatomia Humana. $6^{\circ}$ ed. Rio de Janeiro, Guanabara Koogan, 2006.

Yücel, F.; Egilmez, H. \& Akgün, Z. A Study on the interparietal bone in man. Tr. J. of Medical Sciences, 28:505-9, 1998.

Zambare, B. R. Incidence of interparietal bones in adult skulls. J. Anat. Soc. India, 50(1):11-2, 2001.

Correspondence to:

Dr. Tales Alexandre Aversi-Ferreira.

Universidade Federal de Goiás - Campus Catalão.

Avenida Dr. Lamartine Pinto de Avelar, 1120. Setor Universitário, Catalão/GO.

Departamento de Enfermagem.

BRAZIL

Phone: +55 64 3441-1500

Fax: +55 64 3441-1515

Email: aversiferreira@hotmail.com

Received: 18-07-2009

Accepted: 08-02-2010 